\title{
Morphological and Genetic Variation in the Cosmopolitan Snow Alga Chloromonas nivalis (Volvocales, Chlorophyta) from Japanese Mountainous Area
}

\author{
Kyohei Muramoto ${ }^{1}$, Syou Kato ${ }^{1}$, Tomofumi Shitara ${ }^{2}$, Yoshiaki Hara ${ }^{2}$ \\ and Hisayoshi Nozaki ${ }^{1, *}$

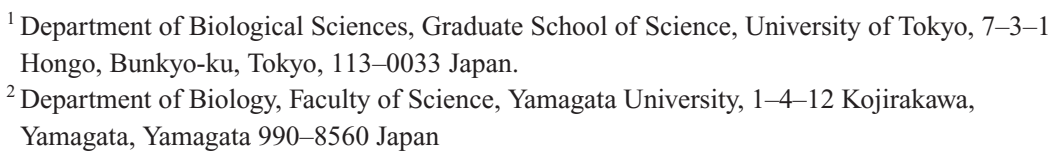

Received March 31, 2008; accepted April 14, 2008

\begin{abstract}
Summary Mature zygotes of the cosmopolitan snow alga Chloromonas nivalis (Chodat) Hoham \& Mullet [=Scotiella nivalis (Chodat) Fritsch] collected from Mt. Gassan, Yamagata Prefecture, were examined by scanning electron microscopy (SEM) and single-cell sequencing of the large subunit of Rubisco $(r b c \mathrm{~L})$ genes. The present SEM demonstrated that Japanese samples have at least two types of flanges on the zygote wall (straight and sigmate). Although these types fell within the morphological variability of $C$. nivalis as reported previously, at least two types of $r b c \mathrm{~L}$ (large subunit of Rubisco) gene sequences were detected by using the single-cell sequencing. Although the information of the $r b c \mathrm{~L}$ genes were limited ( $340-400 \mathrm{bp}$ ), the present phylogenetic analyses revealed that these two Japanese types and $C$. nivalis originating from North America belong to the lineage composed of Chloromonas snow taxa. Thus, C. nivalis might involve multiple cryptic species of Chloromonas. Further ovservations of other stages of life cycle and more detailed phylogenetic analysis are needed to reveal the correct taxonomic identifications of $C$. nivalis.
\end{abstract}

Key words Chloromonas nivalis, Chlorophyceae, Molecular phylogeny, Morphology, Single-cell sequencing, Scanning electron microscopy, Snow algae, Taxonomy, Volvocales.

Snow algae are cold-tolerant freshwater organisms that grow on snow and ice during the early spring thaw season in mountainous areas (Hoham 1980, Hoham and Duval 2001). Traditional taxonomic studies of snow algae were based solely on light microscopy observations of field-collected samples (e.g. Fritsch 1912). Recently, new culture methods, electron microscopy and molecular phylogenetics have been applied to taxonomic studies of snow algae in Antarctica and North America (e.g., Ling 2001, Hoham et al. 2006). However, very little genetic information is available for such samples because field-collected red zygotes of the snow cannot be easily cultured. Fukushima (1963) used light microscopy to study snow algae collected from various mountain areas of Japan. However, the snow algae he described have not been re-examined. Thus, taxonomic re-examinations of Japanese volvocalean snow algae, using culture techniques, electron microscopy and molecular phylogenetic analyses, are needed.

Chloromonas nivalis [=Scotiella nivalis (Chodat) Fritsch] is one of typical snow algal species and its mature zygotes form red snow (Hoham and Mullet 1977). This colour is caused by accumulation of red pigments called "haematochrome" (Kol 1968, Ettl 1983) in the cell. This species is distributed throughout the world and sometimes found in such large quantities that it becomes the

*Corresponding author, e-mail: nozaki@biol.s.u-tokyo.ac.jp 
dominant species of red snow (Siemenska 1951). Life cycle studies and molecular phylogenetic analysis were carried out for North American samples of C. nivalis (Hoham and Mullet 1977, 1978, Hoham et al. 2002). In Japan, Fukushima (1963) found mature zygotes of this alga in reddish brown snow and identified them as "Scotiella nivalis." In the present study, zygotes of this species collected in red snow sample in Japan were examined by light and scanning electron microscopy $(\mathrm{SEM})$ as well as the large subunit of Rubisco $(r b c \mathrm{~L})$ gene sequences determined by the single-cell sequencing.

\section{Materials and methods}

\section{Collection of snow algae samples}

From late May to mid-June 2007, we collected red zygotes of C. nivalis from red snow in Yamagata Prefectural Nature Conservation Park, Mt. Gassan (Nishikawa-machi, Nishimurayamagun, Yamagata, Japan). The coloured snow samples were packed in BLUE MAXTM 50-ml polypropylene conical tubes (Becton Dickinson, Franklin Lakes, NJ, USA) using a stainless-steel spoon, and then packed in a cooler box. The samples were transported immediately to the laboratory and maintained at $5^{\circ} \mathrm{C}$, with a $12 \mathrm{~h}$ light $/ 12 \mathrm{~h}$ dark regime under cool-white fluorescent lamps at $20-40 \mu \mathrm{mol} \cdot \mathrm{m}^{-2} \cdot \mathrm{s}^{-1}$ intensity.

\section{Light microscopy}

Red zygotes were observed using a BX-60 microscope (OLYMPUS, Tokyo, Japan) equipped with Nomarski differential interference optics.

\section{Scanning electron microscopy}

For SEM, red snow samples were poured into a $1.5 \mathrm{ml}$ micro centrifuge tube (Greiner BioOne, Frickenhausen, Germany), and then cleaned by ultrasonic cleaning for $8 \mathrm{~min}$ with a ultrasonic cleaner Vs-Dioo (IUCHISEIEIDO, Osaka, Japan). A small amount of red snow samples (ca. $50 \mu 1$ ) were mounted on brass or aluminium stubs with double-sided adhesive tape. After drying under reduced pressure for $10 \mathrm{~h}$, samples were air-dried over night. Then samples were sputter-coated with gold and viewed with a JSM-5300LV scanning electron microscope (JEOL, Tokyo, Japan).

\section{Molecular phylogenetic analyses}

For field-collected red zygotes, the single-cell sequencing method (Sebastián and O'Ryan 2001) was used. A single red zygote from field samples was isolated using a CH-2 microscope (OLYMPUS, Tokyo, Japan) and transferred into WATSON 0.2-ml PCR tubes (FUKAE KASEI, Hyogo, Japan) containing $5 \mu \mathrm{l}$ sterile distilled water. The PCR tube containing a red snow cell was subjected to three consecutive freeze-thaw cycles to break the cells, alternating baths of liquid nitrogen and water at $90^{\circ} \mathrm{C}$ for $20 \mathrm{~s}$. A TaKaRa Ex TaqTM (TAKARA BIO, Shiga, Japan) reaction mixture $(20 \mu \mathrm{l})$ prepared according to the manufacturer's instructions was then added to the tube for the initial PCR. The reactions were run in a thermal cycler GeneAmp PCR System 9700 (Applied Biosystems, Foster City, CA, USA) with 35 cycles at $94^{\circ} \mathrm{C}$ for $2 \mathrm{~min}, 46^{\circ} \mathrm{C}$ for $2 \mathrm{~min}$ and $66^{\circ} \mathrm{C}$ for $3 \mathrm{~min}$, followed by $72^{\circ} \mathrm{C}$ for $15 \mathrm{~min}$. Because these DNA amplifications were very small, the initial PCR products were immediately purified, using the Wizard SV Gel and PCR Clean-Up System (Promega, Madison, WI, USA), and were then used for secondary PCR, performed as described for the initial PCR. Specific primers [SNOW-F1 (5'-GAATCTTCWACWGGTACTTGGAC-3'), SNOW-F2 (5'-ACTGATGGTTTAACAAGTCTTGA-3'), SNOW-R1 (5'-TATTTGTTTAATTTRTCACGTTC-3'), SNOW-R2 (5'-AARTCTAAWCCACCACGTAAACA-3') and SNOW-R3 (5'ATRAAACGGTCTCTCCAACGCAT- $3^{\prime}$ )] were newly designed based on the published $r b c \mathrm{~L}$ gene sequences from Chloromonas snow taxa. A single operational taxonomic unit (OTU) from the sin- 
Table 1. List of $r b c \mathrm{~L}$ gene sequences used in this study

\begin{tabular}{|c|c|c|}
\hline Taxon & Strain or voucher designation & Accession number \\
\hline \multicolumn{3}{|l|}{ Carteria (Ca.) } \\
\hline Ca. cerasiformis & NIES*-425 & D89768 \\
\hline Ca. crucifera & NIES-421 & D63431 \\
\hline Ca. eugametos & $\mathrm{UTEX}^{* *} 1032$ & D89760 \\
\hline Ca. inversa & NIES-423 & D89766 \\
\hline Ca. obtusa & NIES-428 & D89769 \\
\hline Ca.palmata & NIES-1336 & AB204869 \\
\hline Ca. radiosa & NIES-432 & D89770 \\
\hline Ca. sp. & UTEX 2 & EF113417 \\
\hline \multicolumn{3}{|l|}{ Pseudocarteria $(P)}$. \\
\hline P. mucosa & NIES-522 & AB084335 \\
\hline \multicolumn{3}{|l|}{ Chlamydomonas (Cd.) } \\
\hline Cd. bipapillata & SAG*** 11-47 & AB022225 \\
\hline Cd. mutabilis & UTEX 578 & AB022224 \\
\hline$C d$. radiata & UTEX 966 & AJ001878 \\
\hline \multicolumn{3}{|l|}{ Chloromonas (Cr.) } \\
\hline Cr. augustae & UTEX 1969 & $\mathrm{AB} 022227, \mathrm{AB} 022228$ \\
\hline Cr. brevispina & UTEX SNO132 & AB434263****, AF517072 \\
\hline Cr. chenangoensis & UTEX SNO143 & $\mathrm{AB} 434264 * * * *$ \\
\hline Cr. hohamii & UTEX SNO67 & $\mathrm{AB} 434265 * * * *$ \\
\hline Cr. insignis & NIES-447 & AB022226 \\
\hline Cr. macrostellata & SAG 72.81 & $\mathrm{AB} 022229, \mathrm{AB} 022230$ \\
\hline \multirow[t]{3}{*}{ Cr. nivalis } & UTEX SNO66 & $\mathrm{AB} 434272 * * * *, \mathrm{AF} 517078$ \\
\hline & Gassan-NIV1***** & $\mathrm{AB} 434274 * * * * * *$ \\
\hline & Gassan-NIV2***** & $\mathrm{AB} 434275 * * * * * *$ \\
\hline Cr. palmelloides & SAG 32.86 & $\mathrm{AB} 022530$ \\
\hline Cr. paraserbinowii & SAG 71.72 & AF517074 \\
\hline Cr. pichinchae & UTEX SNO33 & AB434266****, AF517076 \\
\hline Cr. reticulata & UTEX 1969 & $\mathrm{AB} 022534, \mathrm{AB} 022533$ \\
\hline Cr. rosae & UTEX 1337 & $\mathrm{AB} 022535, \mathrm{AB} 022536$ \\
\hline Cr. rosae var. psychrophila & UTEX SNO47 & AF517073 \\
\hline Cr. serbinowii & UTEX 492 & AJ001879 \\
\hline Cr. tughillensis & UTEX SNO88 & $\mathrm{AB} 434273 * * * *$ \\
\hline Cr. variabilis & SAG 79.81 & AF517077 \\
\hline \multicolumn{3}{|l|}{ Chlainomonas (Ci.) } \\
\hline \multirow[t]{2}{*}{ Ci. kolii } & P. M. Novis & DQ885963 \\
\hline & CHR586425******* & \\
\hline \multirow[t]{2}{*}{ Ci. rubra } & P. M. Novis & DQ885969 \\
\hline & CHR586427******* & \\
\hline
\end{tabular}

\footnotetext{
* Microbial Culture Collection at the National Institute for Environmental Studies (Kasai et al. 2004).

** Culture Collection of Algae at the University of Texas at Austin (Starr and Zeikus 1993).

*** Sammlung von Algenkulturen at the University of Göttingen (Schlösser 1994).

$* * * *$ Sequenced in Muramoto et al. (unpublished).

$* * * * *$ Sequenced in the present study.

****** Specimen of red zygotes collected from Mt. Gassan, Yamagata Pref., Japan.

$* * * * * * *$ Voucher specimen.
}

gle-cell sequencing method was based on identical sequences obtained from at least three different cells.

The coding regions $(1,128 \mathrm{bp}$, see Nozaki et al. 2003) of the $r b c \mathrm{~L}$ gene sequences from 16 Chloromonas strains, eight Carteria strains, three Chlamydomonas strains, two Chlainomonas specimens and one Pseudocarteria strain (Table 1) were aligned with the short sequences (340-400 bp) from Chloromonas nivalis (Gassan-NIV1 and Cassan-NIV2) provided by single-cell sequencing methods, using ClustalX (Thompson et al. 1997). From this alignment, a distance ma- 
trix was calculated by applying the two-parameter method (Kimura 1980) in ClustalX. A phylogenetic tree was constructed using the neighbour-joining (NJ) algorithm (Saitou and Nei 1987) in ClustalX, and the robustness of the resulting lineages was tested using bootstrap analysis (Felsenstein 1985) with 1,000 replications. Based on the same alignment data, a maximum parsimony (MP) analysis (including a bootstrap analysis based on 1,000 replications) was performed, based on ten random replications of the general heuristic search, using the tree-bisection-reconnection branch-swapping algorithm in PAUP* 4.0b10 (Swofford 2003). The Carteria/Pseudocarteria OTUs were designated as the outgroup, as they represent the basal lineage within the Volvocales (Nozaki et al. 2003).

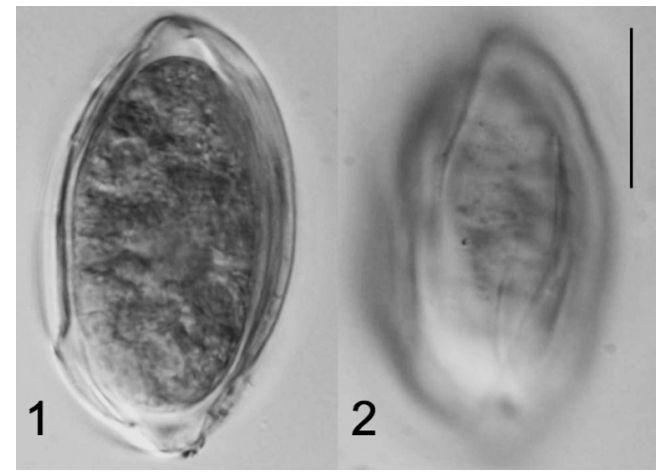

Figs. 1, 2. Light microscopy of two different views of a mature zygote of Chloromonas nivalis collected from red snow samples in Mt. Gassan, shown at the same magnification. Scale bar $=10 \mu \mathrm{m}$. Fig. 1. Optical section. Note that contents are not visible because of red pigments accumulating in the protoplast. Fig. 2. Surface view showing flanges on the surface of cell wall.

\section{Results and discussion}

\section{Lighit microscopy}

Light microscopic features of zygotes of C. nivalis collected in Mt. Gassan were essentially the same as those of the description by Fukushima (1963). The zygotes were ellipsoidal or oval in shape, measuring $20-28 \mu \mathrm{m}$ long and 11-15 $\mu \mathrm{m}$ wide (Figs. 1, 2). Because a large quantity of carotenoid pigments in the protoplast, intracellular structures were not visible. There were several flanges developing on the cell wall. Attempts to establish cultures of these zygotes were unsuccessful.

\section{Scanning electron microscopy}

The surface morphology of the cell wall of $C$. nivalis were clearly imaged by using SEM. Differences were not detected in cell

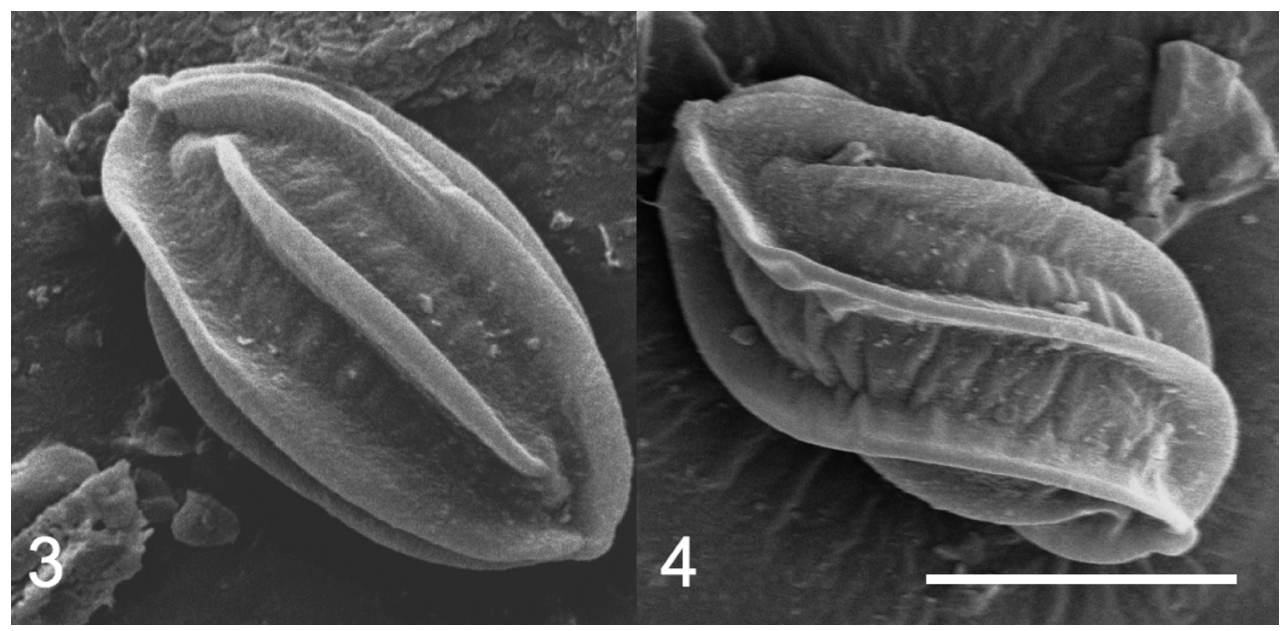

Figs. 3, 4. Scanning electron micrographs of two types of mature zygotes of Chloromonas nivalis collected from red snow samples in Mt. Gassan, shown at the same magnification. Scale bar $=10 \mu \mathrm{m}$. Fig. 3. Zygote developing "straight" flanges. Fig. 4. Zygote developing "sigmate" flanges. 


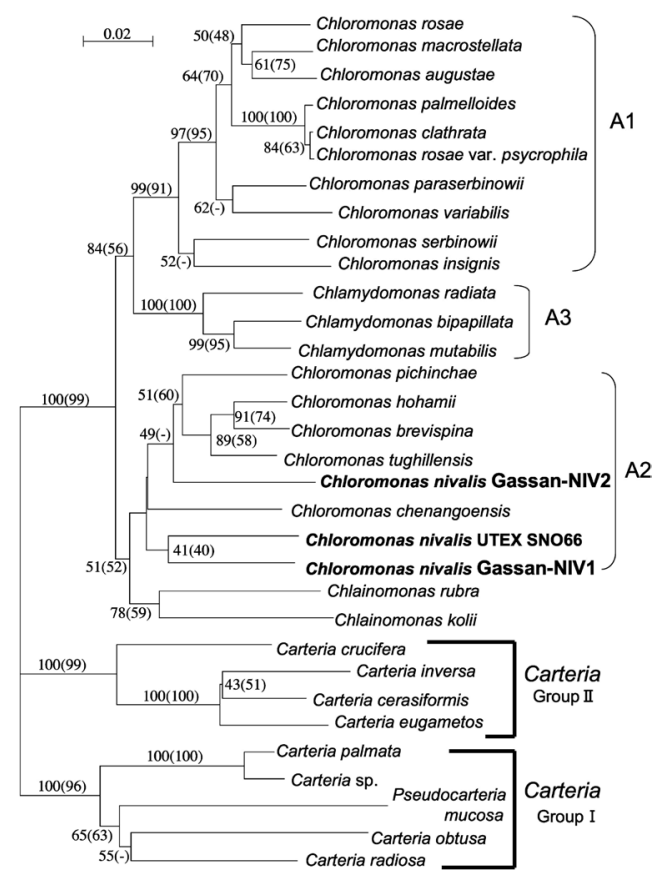

Fig. 5. Phylogenetic tress based on the $r b c \mathrm{~L}$ gene sequences (1128 bp) from of Chloromonas taxa and their related volvocaleans (Table 1). The tree was constructed by neighbor-joining (NJ) method (Saitou and Nei, 1987) based Kimura's distances (Kimura 1980). Numbers without and within parentheses near branches represent bootstrap values $(>40 \%)$ calculated by $\mathrm{NJ}$ and maximum parsimony analyses, respectively. Branch lengths are proportional to Kimura's distances that are present by the scale bar near the tree. A1, A2 and A3 correspond to subclades 1, 2 and 3, respectively, in Clade A in Hoham et al. (2002). size, but at least two types of flange's forms [straight (Fig. 3) and sigmate (Fig. 4)] were found. However, this morphological variability corresponds to variation within $C$. nivalis as described previously (Hoham and Muller 1977, 1978). Distinguishing these characteristics was difficult using the present light microscopes.

\section{Single-cell sequencing}

Because it was unsuccessful to obtain $r b c \mathrm{~L}$ gene sequences from zygotes of $C$. $n i$ valis using previous published primers (Nozaki et al. 1995, 1997) in the single-cell sequencing, specific primers newly designed (see Materials and methods) were used for single-cell sequencing of the zygotes. As a result, the partial sequences of $r b c \mathrm{~L}$ gene (340-400 bp) were determined. In addition, it was found that zygotes of $C$. nivalis in Japan have at least two $r b c \mathrm{~L}$ haplotypes (Gassan-NIV1 and GassanNIV2).

Molecular phylogenetic analysis of the chloroplast rbcL gene sequences

In the phylogenetic analyses of the $r b c \mathrm{~L}$ gene sequences, two haplotypes of $C$. nivalis (Gassan-NIV1 and Gassan-NIV2) were both located within a clade consisting of Chloromonas snow taxa (corresponding to subclade 2 in Clade A [Hoham et al. 2002]; Fig. 5). Gassan-NIV1 formed a monophyletic clade with Chloromonas nivalis from North

America (UTEX SNO 66), but with low bootstrap values $(<50 \%)$. On the other hand, GassanNIV2 was separated from Gassan-NIV1 and C. nivalis from North America, and was positioned basally to the monophyletic group composed of C. pichinchae (Lagerheim) Wille, C. hohamii Ling \& Seppelt, C. brevispina (Fritsch) Hoham et al. and C. tughillensis Hoham et al. (with 51\% and $60 \%$ bootstrap values in NJ and MP analyses) (Fig. 5). These results might suggest possibility that C. nivalis represent collective of multiple cryptic species of Chloromonas snow taxa.

Although we observed two morphological types of the Japanese samples by SEM (Figs. 3, 4), it was not possible to determine which morphological type corresponds to one of the two haplotypes because distinguishing the two morphological types was difficult especially with the light microscope used for the single-cell sequencing. Further observations of other stages of life cycle and more detailed phylogenetic analysis are needed to reveal the correct taxonomic identifications of $C$. nivalis.

\section{Acknowledgements}

We would like to thank Drs. Akihiko Nakano, Takashi Ueda and Tomohiro Uemura (Universi- 
ty of Tokyo) and members of their laboratory for permitting us to use their cold room. Thanks are also due to Mr. Minoru Hasei (Hasei corporation, Gunma, Japan) for his kind help collecting the snow samples, and to Drs. Hiroshi Fukushima (Institute of Algae) and Kazuharu Misawa (RIKEN) for their kind suggestions and discussions. This work was supported by Grant-in-Aid for Creative Scientific Research (No. 16GS0304 to HN) and by Grant-in-Aid for Scientific Research (No. 17370087 to HN) from the Ministry of Education, Culture, Sports, Science and Technology, Japan.

\section{References}

Ettl, H. 1983. Süßwasserflora von Mitteleuropa 9. Chlorophyta I, Phytomonadina. Gustav Fischer Verlag, Stuttgart.

Felsenstein, J. 1985. Confidence limits on phylogenies: An approach using the bootstrap. Evolution 39: 783-791.

Fritsch, F. E. 1912. Freshwater algae collected in the South Orkneys by Mr R. N. Rudmose Brown, B.Sc., of the Scottish National Antarctic Expedition, 1902-1904. Bot. J. Linn. Soc. 40: 293-338.

Fukushima, H. 1963. Studies on cryophytes in Japan. Yokohama Munic. Univ. Ser. C. Nat. Sci. 43: 1-146.

Hoham, R. W. 1980. Unicellular chlorophytes-snow algae. In: Cox, E. R. Phytoflagellates. Elsevier/North Holland, New York, pp. 61-84.

—, Berman, J. D., Rojers, H. S., Felio, J. H., Ryba, J. B. and Miller, P. R. 2006. Two new species of green snow algae from Upstate New York, Chloromonas chenangoensis sp. nov. (Volvocales, Chlorophyceae) and the effects of light on their life cycle development. Phycologia 45: 319-330.

-, Bonone, T. A., Martin, C. W. and Leebens-Mack, J. H. 2002. A combined 18S rDNA and $r b c$ L phylogenetic analysis of Chloromonas and Chlamydomonas (Chlorophyceae, Volvocalese) emphasizing snow and other cold-temperaure habitats. J. Phycol. 38: 1051-1064.

- and Duval, B. 2001. Microbal ecology of snow and freshwater ice with emphasis on snow algae. In: Jones, H. G., Pomeroy, J. W., Walker, D. A. and Hoham, R. W. Snow Ecology. An Interdisciplinary Examination of Snow-covered Ecosystem. Cambridge University Press, Cambridge, pp. 168-228.

- and Mullet, J. E. 1977. The life history and ecology of the snow alga Chloromonas cryophila sp. nov. (Chlorophyta, Volvocales). Phycologia 16: 53-68.

— and - 1978. Chloromonas nivalis (Chod.) Hoh. \& Mull. comb. nov., and additional comments on the snow alga, Scotiella. Phycologia 17: 106-107.

Kasai, F., Kawachi, M., Erata, M. and Watanabe, M. M. 2004. NIES-Collection. List of Strains. Microalgae and Protozoa. 7th ed. National Institute for Environmental Studies, Tsukuba, Japan, pp. 257

Kimura, M. 1980. A simple method for estimating evolutionary rate of base substitutions through comparative studies of nucleotide sequences. J. Mol. Evol. 16: 111-120.

Kol, E. 1968. Kryobiologie. Biologie und Limnologie des Schnees und Eises. I. Kryovegetation. In: Elster H.-J. and Ohile W. Die Binnege wässer, Vol. 24. Schweizerbart' sche Verlagsbuchhandlung, Stuttgart, pp. 1-216.

Ling, H. U. 2001. Snow algae of the Windmill Islands, continantal Antarctica: Desmotetra aureospora, sp. nov. and Antarctica, comb. nov. (Chlorophyta). J. Phycol. 37: 160-174.

Nozaki, H., Ito, M., Sano, R., Uchida, H., Watanabe, M. M. and Kuroiwa, T. 1995. Phylogenetic relationships within the colonial volvocales (Chlorophyta) inferred from $r b c$ L gene swquence data. J. Phycol. 31: 979-979.

—, - , Uchida, H., Watanabe M. M. and Kuroiwa, T. 1997. Phylogenetic analysis of Yamagishiella and Platydorina (Volvocaceae, Chlorophyta) based on $r b c \mathrm{~L}$ gene sequences. J. Phycol. 33: 272-278.

- Misumi, O. and Kuroiwa, T. 2003. Phylogeny of the quadriflagellate Volvocales (Chlorophyceae) based on chloroplast multigene sequences. Mol. Phylogenet. Evol. 29: 58-66.

Saitou, N. and Nei, M. 1987. The neighbor-joining method: a new method for reconstructing phylogenetic trees. Mol. Biol. Evol. 4: 406-425.

Schlösser, U. G. 1994. SAG-Sammlung von Algenkulturen at the University of Göttingen. Catalogue of strains. Bot. Acta, 107: 113-186.

Sebastián, C. R and O’Ryan, C. 2001. Single-cell sequencing of dinoflagellate (Dinophyceae) nuclear ribosomal genes. Mol. Ecol. Notes 1: 329-331.

Siemenska, J. 1951. The red snow in Tatra. Acta Soc. Bot. Polon. 21: 1-4.

Starr, R. C. and Zeikus, J. A. 1993. UTEX: The culture collectuion of algae at the University of Texas at Austin. J. Phycol. 29: 1-106 (Suppl.).

Swofford, D. L. 2003. PAUP*. Phylogenetic Analysis Using Parsimony (* And Other Methods). Version 4.0b10 Sinauer Associates, Sunderland, Massachusetts.

Thompson, J. D. Gibson, T. J. Plewniak, F. Jeanmougin, F. and Higgins, D. G. 1997. The Clustal X windows interface: flexible strategies for multiple sequence alignment aided by quality analysis tools. Nucleic Acids Res. 25: 4876-4882. 